J. Clin. Chem. Clin. Biochem.

Vol. 17, 1979, pp. 627-631

\title{
Bromocresol Purple, a Non-Specific Colour Reagent for the Determination of Serum Albumin
}

By R. M. Tel, Janny de Jong and G. T. Berends

Clinical Chemical Laboratory, St. Elisabeth's Hospital, Haarlem, The Netherlands

(Received February 12/June 7, 1979)

Summary: The determination of serum albumin with the dye reagent bromocresol purple was investigated.

We found that bromocresol purple is not a specific reagent for albumin, but that serum proteins in the $\alpha$-, $\beta$-, and $\boldsymbol{\gamma}$-globulin fractions also react with this dye. Similar results were obtained for bromocresol green.

Furthermore there is a great difference in absorbance between human and bovine albumin solutions (having the same concentration) when using the bromocresol purple reagent. Most probably this is a result of the difference in interaction of the reagent with the substrate.

Although the standard curves with the bromocresol purple method were more linear (especially at higher albumin concentrations) than those obtained with the bromocresol green method, we still prefer the bromocresol green technique to the bromocresol purple technique, because its results are more comparable with those of other methods.

Moreover in quality control and calibration procedures, strong deviations from the recommended values are obtained when non-human sera are analyzed with the bromocresol purple method.

For reasons of accuracy more specific methods are preferable.

\section{Bromkresolpurpur, ein nicht-spezifisches Farbreagenz zur Bestimmung von Serum-Albumin}

Zusammenfassung: Die Bestimmung von Serum-Albumin mit dem Farbreagenz Bromkresolpurpur wurde untersucht. Wir fanden, daß Bromkresolpurpur kein spezifisches Reagenz für Albumin ist und Serumproteine in der $\alpha$-, $\beta$ - und $\gamma$-Globulinfraktion auch mit diesem Farbstoff reagieren. Ähnliche Ergebnisse wurden mit Bromkresolgrün erhalten. Ës besteht ferner ein großer Unterschied in der Absorption von Albumin des Menschen und des Rindes gleicher Konzentration, wenn Bromkresolpurpur als Reagenz benutzt wird. Sehr wahrscheinlich beruht dies auf unterschiedlichen Wechselwirkungen des Reagenz mit dem Protein.

Obwohl die Standardkurven mit der Bromkresolpurpur-Methode - besonders bei höheren Albuminkonzentrationen - geradliniger sind als die mit der Bromkresolgrün:Methode, ziehen wir unter Berücksichtigung des Vergleichs der Ergebnisse mit denen anderer Methoden doch die Bromkresolgrün-Methode der Bromkresolpurpur-Methode vor.

Darüberhinạaus werden bei Verwendung von Seren, die nicht vom Menschen stammen, in Qualitätskontroll- und Standardisierungsverfahren mit der Bromkresolpurpur-Methode starke Abweichungen von den angegebenen Werten erhaltẹn.

Hinsichtlich der Genaiuigkeit sind spežifischere Methoden vorzuziehen.

\section{Introduction}

The determination of serum albumin with bromocresol green is a well known procedure (1-7). Unfortunately the use of this colour reaction has some disadvantages. The reaction is not a specific one because other serum proteins and some drugs (4) also give a colour. Upon standing, the reagent partly precipitates, causing turbidity (4).

Recently a new colour reagent, bromocresol purple was documented $(4,8,9,10)$. The authors indicated that this reagent was preferred to bromocresol green because of the specificity of bromocresol purple for serum al- 
bumin. No reactions were observed with other serum proteins. Only large amounts of bilirubin would hinder the determination (4).

In order to see whether this method could be used for our serum albumin determinations we started to investigate this bromocresol purple technique. In some quality control experiments (National Foundation of Quality Control of Clinical Chemical Hospital Laboratories, Nijmegen) we observed very large deviations from the mean values.

The measurements were repeated with new control sera (with the same composition) but the differences still remained. We therefore undertook a detailed investigation of this determination.

\section{Materials and Methods}

\section{Reagents}

The working bromocresol green solution was prepared according to the method of McPherson (2).

The working bromocresol purple solution was prepared according to the method of Pinnell (4). We used $2 \mathrm{ml}$ instead of $1 \mathrm{ml}$ of the bromocresol purple reagent (see Results and 1.c. (10)).

Procedure (bromocresol purple and bromocresol green methods) To $10 \mathrm{ml}$ of the dye reagent was added $50 \mu 1$ of serum. After mixing, the colour change was read (against a reagent blank) as soon as possible on a Beckman Spectrophotometer, Model 26, at $603 \mathrm{~nm}$ for the bromocresol purple method, and at $635 \mathrm{~nm}$ for the bromocresol green method. In both cases a human albumin standard and/or a standard curve was used to estimate the amount of serum albumin. Human and bovine albumin were obtained from Hoechst-Behring.

\section{Electrophoresis of serum proteins}

Electrophoresis, followed by staining with the dye reagents bromocresol purple and bromocresol green

About $3.0 \mu \mathrm{l}$ of serum was applied to a cellogel cellulose acetate strip (Chemetron, Italy) and was run for $45 \mathrm{~min}$ at a constant potential difference of $250 \mathrm{~V}$ at room temperature. After electrophoresis, fixation of the proteins and deacetylation of the strips were performed in one step by soaking the strips for 5 to 10 minutes in a mixture of $10 \mathrm{~g} \mathrm{NaOH}+500 \mathrm{ml}$ distilled water $+430 \mathrm{ml}$ ethanol $(960 \mathrm{ml} / \mathrm{l})$. During the process the strips shrank, losing their original size. This shrinking process is complete after about 5 minutes. The strips were steeped in a buffer with $\mathrm{pH}$ of about 3-4 to change the $\mathrm{pH}$ to that of the dye reagent, then immersed in the dye reagent for about 15 minutes.

\section{Routine protein electrophoresis}

About $0.12 \mu \mathrm{l}$ of serum was applied to the cellulose acetate strips (Sartorius Membrane filter) and run for $30 \mathrm{~min}$ at a constant potential difference of $250 \mathrm{~V}$ at room temperature. Next the strips were stained in a bath of amido black for $5 \mathrm{~min}$., then decolorized in a mixture of acetic acid and methanol $(100 \mathrm{ml}+900 \mathrm{ml})$ for 5 minutes.

After $3 \mathrm{~min}$ in a tränsparency bath (mixture of $700 \mathrm{ml}$ dioxane $+300 \mathrm{ml}$ iso-butanol), the strips were dried at $100^{\circ} \mathrm{C}$ for 10 minutes.

\section{Evaluation}

The scans were carried out on a Clifford Densicomp, model 445.

M-Partigen Immunodiffusion Plates for Albumin Determination The manufacturer's instructions for the M-Partigen Immunodif= fusion Plates (Hoechst-Behring) were followed. The precipitate circles were measured with a Measuring Viewer for Immunoanalysis (Behringwerke) and the albumin content reạd from the standard curve.

\section{Total protein determ ination}

The total protein determinations were carried out on an Auto Analyzer II continuous flow system (Technicon instruments) using the biuret reaction.

\section{Results}

The standard curves of some albumin solutions are shown in figure 1.

Only the results for albumin solutions in distilled water are given, because the same values (within the experimental error) were found for albumin in physiological salt solution ( $9 \mathrm{~g}$ sodium chloride in one liter of water). Although bovine albumin gives a straight standard curve
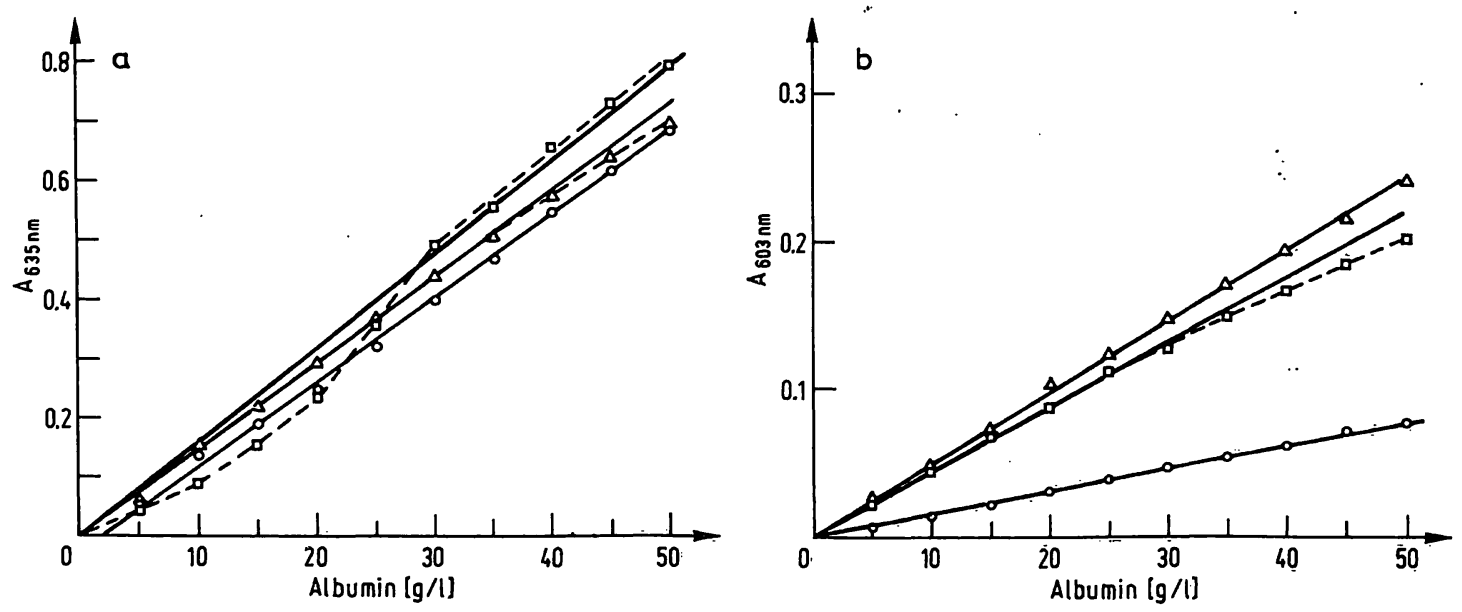

Fig. 1. Standard curves of albumin solutions using both colour methods. a. Bromocresol green:

$\triangle$ Human Albumin (stock solution, $3 \mathrm{ml} / \mathrm{l}$ )

0 Boyine Albumin (stock solution, $3 \mathrm{ml} / \mathrm{l}$ )

- Human Albumin (stock solution, $6 \mathrm{ml} / \mathrm{l}$ )

b. Bromocresol purple:

$\triangle$ Human Albumin (stock solution, $2 \mathrm{ml} / \mathrm{l}$ )

0 Bovine Albumin (stock.solution, $2 \mathrm{ml} / 1$ )

o Human Albumin (stock solution, $1 \mathrm{ml} / 1$ ) 


\section{Erhöhen Sie Ihre Sicherheit:}

II

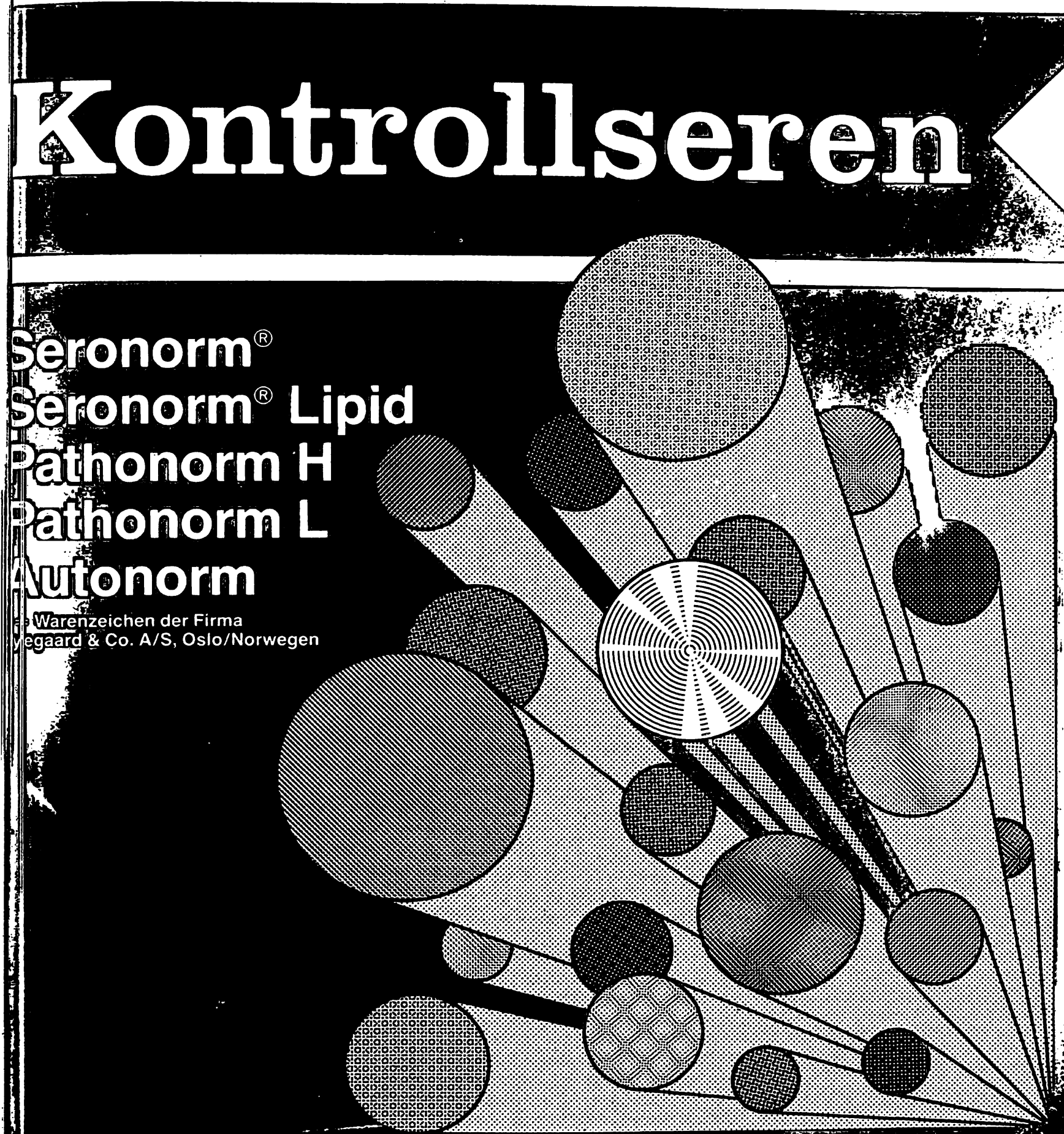

Die zur Herstellung verwendeten Seren stammen von gesunden Tieren: Als besondere Vorsichtsmaßnahme werden alle Chargèn zusätzlich radio-immunologisch auf Australia-Antigen gepruft: Es besteht also kein Infektionsrisiko im Labor.

Die Kontrollseren sind nicht dialysiert.

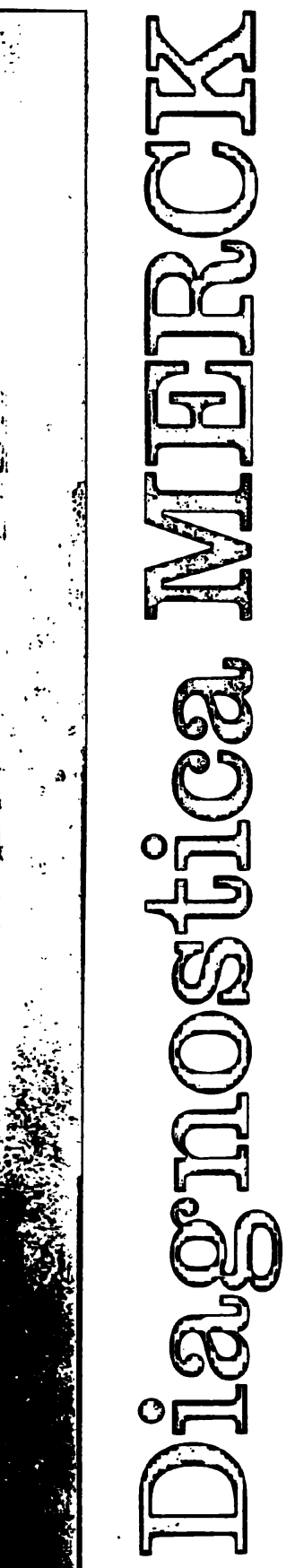

Proteine, Spurenelemente und Polypeptide sind also enthalten.

Damit ist sichergestellt, daß Kontrolle und Proben unter den gleichen Bedingungen analysiert werden:

Stabilisatoren oder andere Fremdsubstanzen sind nicht zugefügt.

Bitte fordern Sie ausführliche Unterlagen an.

E. Merck

Frankfurter Straße 250 

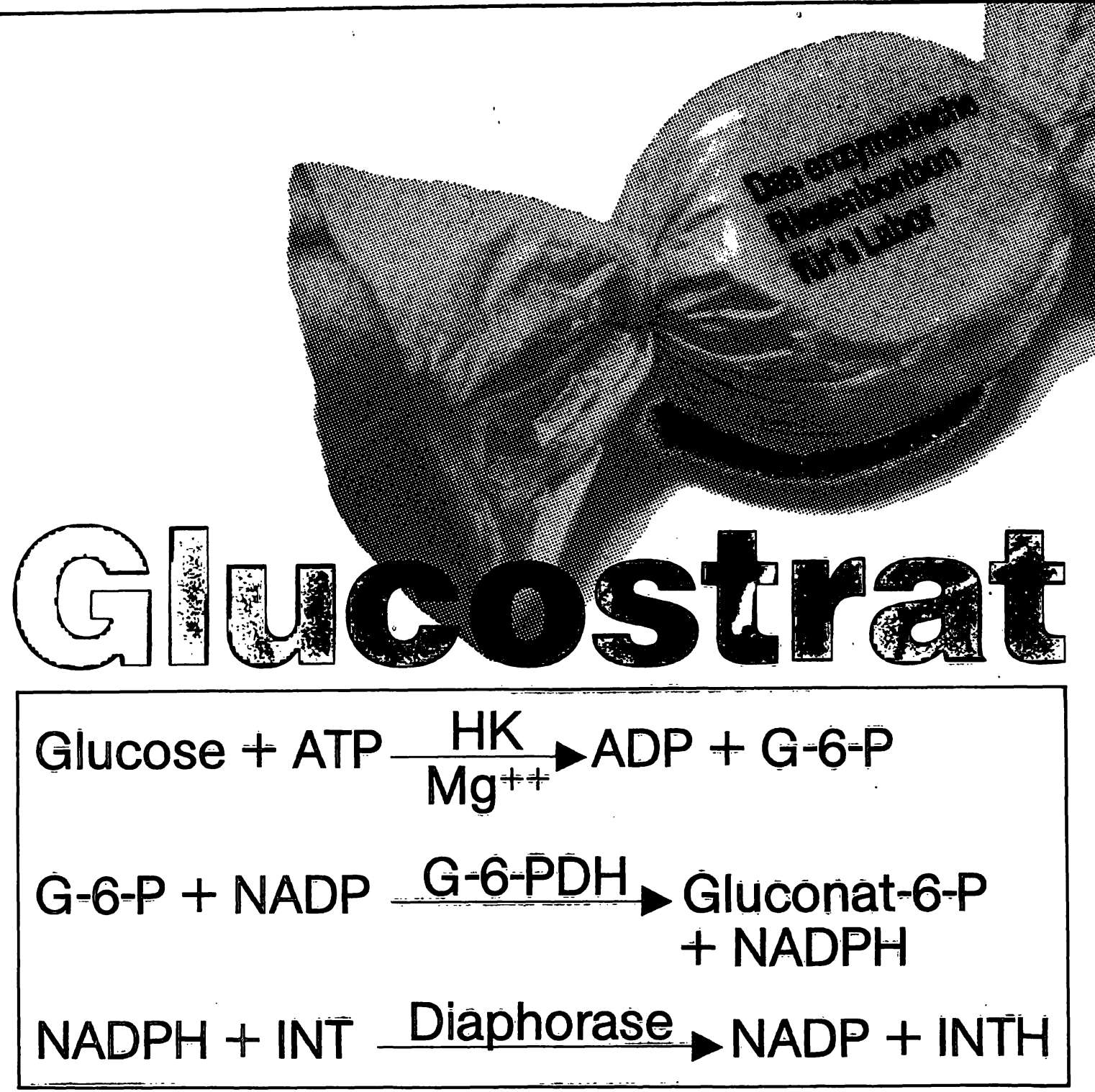

Wir haben aus der Exklusivmethode Hexokinase/ G6P-DH eine kostengünstige Methode für die Routine gemacht. Durch Kopplung mit einem roten Azofarbstoff (INTH). Das Reaktionsprinzip bleibt dasselbe und entspricht jeder anderen Hexokinase/G6P-DH-Miethode. Die Spezifität bleibt dieselbe. Die Spezifität einer Referenzmethode.

Hexokinase/G6P-DH-Methoden gelten als Referenzmethoden zur Bestimmung der Glucose. Bei den meisten dieser Methoden wird das beim Abbau der Glucose durch Reduktion von NADP sich bildende NADPH im UV-Bereich gemessen. Eiri kostspieliges Vorgehen, das hohe Konzentrationen von NADP benötigt.
Nur ein Prinzip, das z.B. selbst immer wieder NADP aus NADPH zurückgewinnt, kann die Kosten reduzieren: Das Glucosträt-Prinzip. Deshälb ist Glucostrat so kostengünstig. Bei gleicher Zuverlässigkeit und gleicher Spezifität wie die UV-Methode. Genau das Richtige für das anspruchsvolle Routinelabor.
Art.-Nr. 842002 Glucostrat 120 Ansätze DM 42--* Art.-Nr. 842004 Glucostrat 300 Ansätze DM 67,50* * (unverbindliche Preisempfehlung zuzüglich Mehrwertsteuer) 
(bromocresol purple me thod), it can be seen that the absorption is much less than in the case of human albumin solution. A similar effect was previously reported by Pinnell \& Northam (4).

The absorption differences between human and bovine albumin solutions are small when measured by the bromocresol green method. Although hardly visible on figure 1 a, the curves show a little "S-character" as estimated by repeated experiments.

The positions of the absorption maxima were found to be at $635 \mathrm{~nm}$ for the human albumin bromocresol green complex and at $636 \mathrm{~nm}$ for the bovine albumin bromocresol green complex. The corresponding values for the bromocresol purple complexes were found to be at 606 $\mathrm{nm}$ and $611 \mathrm{~nm}$.

For the bromocresol purple method we found a better calibration curve if twice $(2 \mathrm{ml}, 0.04 \mathrm{~mol} / 1$ bromocresol purple solution) the usual concentration (4) was used. During the preparation of this manuscript Haythorn (10) described the same effect. For the bromocresol green procedure, however, this was certainly not the case, and a pronounced "S-character" could be observed (fig. 1 a).

Calibration curves obtained by both colour techniques from a pool serum (containing about $50 \mathrm{~g}$ albumin per liter) have the same shape as the standard curves of the human albumin solution. Straight lines were obtained with both methods if a mixture of $50 \mu 1$ of albumin solution in the working dye reagent solution was further diluted.

With the bromocresol purple method the amount of albumin of a standard human serum (Hoechst-Behring) revealed a value of $63 \mathrm{~g} / 1$, and with the bromocresol green method a value of $58 \mathrm{~g} / \mathrm{l}$. The recommended and analytical value, however, is $50.9 \mathrm{~g} / \mathrm{l}$. Since standard human serum is used as our standard for the immunodiffusion technique, we estimated the value of an albumin solution containing 50 and $60 \mathrm{~g} / 1$ by this technique. Respective values of 49.3 and $61.8 \mathrm{~g} / 1$ were found.

In order to investigate whether interfering substances in the serum might be responsible for these high values for the albumin in the Behring serum by both colour methods, we made dilutions of this standard human serum with physiological saline. The absorbance, obtained from the addition of the colour reagents to these solutions, resulted in a straight line.

Addition of a known amount of human albumin to a previously assayed serum revealed that the observed value is equal to the theoretical one.

From the literature it was known that the colour reaction with bromocresol green is not a specific one for albumin determination but that slow reactions with other serum proteins cause an increased absorbance with in- creasing time (4). With pure human as well as bovine albumin we found no increase of the absorbance either with the bromocresol purple or the bromocresol green procedure.

With some arbitrary human sera, a time dependent increase of the absorbance was observed with the bromocresol green method (about $5 \%$ within 30 minutes, and about $7 \%$ after 5 hours). In contrast to the results of other studies $(4,8,9,10)$, a comparable increase was also found with the bromocresol purple method. This increase could be due to a slow unspecific reaction.

We therefore investigated this problem with further electrophoresis experiments. These experiments indicated that other serum proteins are also responsible for a colour development. We observed colours on the positions of the $\alpha_{2^{-}}, \beta$, and $\gamma$-fractions, as indicated in Figure 2.

The colouring was clearly visible if an excess of bromocresol green or bromocresol purple reagent relative to the method as described under "Materials and Methods" was present.

In order to allow a good comparison between the results of the dye method and those of the electrophoresis it is necessary to choose equal concentrations. Two methods were considered:

(1) Dilution of the colour reagent which has the disadvantage that all reactions would be retarded, and

(2) Placement of one strip (after electrophoresis and deacetylating) in $0.6 \mathrm{ml}$ of the dye reagent. We chose the latter possibility. A strip was placed in a little plastic bag (about $7 \times 3 \mathrm{~cm}$ ). Then $0.6 \mathrm{ml}$ of the colour reagent was added and the bag was sealed. For $15 \mathrm{~min}$ this bag was rotated in all directions by hand. Next the bag was cut open, and the strip was washed in a buffer ( $\mathrm{pH}$ about 3 ). The strip was sealed again and scanned. Colouring of the $\alpha-, \beta$-, and $\gamma$-globulin positions was clearly visible.

We determined the serum albumin for a number of unselected sera using different techniques: bromocresol purple method, bromocresol green method, M-partigen immunodiffusion plates, and a combination of the determination of total protein and protein scan. We made use of a human albumin standard $(50 \mathrm{~g} / \mathrm{l})$ and an arbitrary human serum.

The amount of albumin of the latter $(39.1 \mathrm{~g} / \mathrm{l})$ was estimated by a total protein determination with the biuret reaction and a tenfold electrophoresis followed by scanning.

Table 1 shows the great difference between the results of the different methods.

In quality control we obtained very large deviations from the mean values using the bromocresol purple 

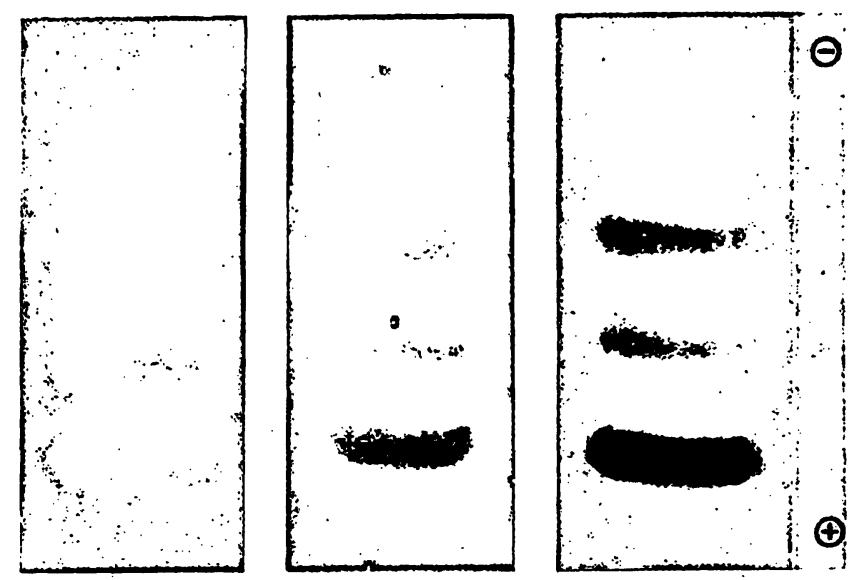

Fig. 2. Protein staining after electrophoresis.

Left : staining with bromocresol green

Middle: staining with bromocresol purple

Right .: staining with amido black

Tab. 1. Determination of serum albumin with bromocresol purple (BCP), bromocresol green (BCG), total protein/ protein scan(TP/PS), and M-partigen immunodiffusion (MPID) methods.

a. Standard: Human albumin solution containing $50 \mathrm{~g} / \mathrm{l}$.

\begin{tabular}{lllll}
\hline No. & BCP & BCG & TP/PS & MPID \\
\hline SHS $^{1}$ & 59.3 & 56.0 & & 50.9 \\
SHA $^{2}$ & 50.0 & 50.0 & 50.0 & 49.3 \\
1 & 39.4 & 46.5 & 40.6 & 38.3 \\
2 & 32.5 & 43.8 & 41.9 & 38.4 \\
3 & 26.5 & 41.5 & 36.9 & 35.3 \\
4 & 24.0 & 36.5 & 33.0 & 29.7 \\
5 & 44.0 & 44.8 & 45.8 & 45.4 \\
6 & 33.0 & 52.8 & 47.4 & 49.2 \\
7 & 48.3 & 51.2 & 45.1 & 51.0 \\
\hline
\end{tabular}

(1) SHS = Standard Human Serum. Recommended albumin content: $50.9 \mathrm{~g} / \mathrm{l}$. This standard was used for the MPID method.

(2) SHA = Standard Human Albumin Solution containing $50 \mathrm{~g} / 1$

b. Standard: Human serum containing $39.1 \mathrm{~g} / 1$ albumin

\begin{tabular}{clll}
\hline No. & BCP & BCG & TP/PS \\
\hline Standard & 39.1 & 39.1 & 39.1 \\
1 & 41.8 & 40.4 & 47.0 \\
2 & 44.8 & 37.3 & 43.5 \\
3 & 44.8 & 40.0 & 40.3 \\
4 & 43.5 & 43.0 & 43.3 \\
5 & 37.5 & 36.6 & 22.5 \\
6 & 36.4 & 39.3 & 41.7 \\
7 & 47.0 & 41.2 & 29.5 \\
8 & 34.4 & 38.4 & 41.5 \\
9 & 43.8 & 38.6 & 45.2 \\
10 & 39.3 & 39.7 & 35.6 \\
\hline
\end{tabular}

method when non-human sera were analyzed. The use of the bromocresol green procedure gave a much better agreement with the mean values.

\section{Discussion}

Figure 1 shows that the concentration of the dye reagent has an influence upon the shape of the standard curve. In the case of the bromocresol purple method $(1 \mathrm{ml}$, $0.04 \mathrm{~mol} / \mathrm{l}$ ) the curve is flattened at higher albumin concentration (about $30 \mathrm{~g} / \mathrm{l}$ ). This flattening of the curve could be corrected by taking a double bromocresol purple concentration, as compared with the paper of Pinnell \& Northam (4). For the bromocresol green method doubling of the concentration caused an " $S$ like" calibration curve. This "S-like" calibration curve is not a result of deviation from Beer's law because a straight line was observed when the solution containing $10 \mathrm{ml}$ of bromocresol green reagent and $50 \mu \mathrm{l}$ of human albumin standard $(50 \mathrm{~g} / \mathrm{l})$ was diluted.

We found a very strong difference in absorbance between a bovine and a human albumin standard for the bromocresol purple. Since the absorption maxima between the complexes of human and bovine albumin with bromocresol purple are quite different and since the chemical compositions of human and bovine albumin are not exactly the same (11) we believe that different interactious could be responsible for this effect. Therefore we believe that an earlier explanation of Pinnell \& Northam (4), who suggested different reactivities between the two types of albumin, is too restricted. 
Until now it was believed that bromocresol purple was a specific dye reagent for albumin $(4,8,9,10)$. Our results prove that this statement is not correct.

Our electrophoresis experiments, indicating a colour development with serum proteins in the $\alpha_{2-}, \beta$-, and $\gamma$-fractions, agree with this conclusion. Human albumin only gives a colour at the albumin position. It was shown that the double bromocresol purple concentration (4) is not responsible for this phenomenon, because the same results were obtained with the concentrations as used by Pinnell \& Northam (4).

In contrast to the results of Webster (3) and Louderback (9), we observed colouring of the $\gamma$-globulins in serum with bromocresol green.

Finally a number of methods, including bromocresol green and bromocresol purple were compared (tab. 1). The values of the bromocresol green method tend to be higher than those obtained with the M-partigen immunodiffusion plates. For the bromocresol purple method some values are higher, while others are lower than those obtained by the immunodiffusion method. The higher values could be understood by assuming unspecificity of the reaction, but for the lower values we have no satisfactory explanation.

Although it was known from the literature that the bromocresol purple method underestimated the amount of serum albumin for icteric patients $(4,8)$ we believe that other factors must also be taken into account to explain these values. The different forms of the calibration curves, obtained with the bromocresol purple and the bromocresol green methods, suggest different reaction mechanisms between the reactions of albumin with these dyes.

In our experiments a human albumin solution $(50.0 \mathrm{~g} / 1)$ was used as a standard. In order to rule out the possibility that a less suitable standard was chosen, we repeated the experiments for the greater part, using a human serum standard (albumin content $39.1 \mathrm{~g} / 1$ ). Table 1 shows that com- · parable results were obtainẹ.

\section{References}

1. Doumas, B. T., Watson, W. A. \& Biggs, H. G. (1971) Clin. Chim. Acta 31, 87-96.

2. McPherson, I. G. \& Everard, D. W. (1972) Clin. Chim. Acta 37, 117-121.

3. Webster, D., Bignell, A. H. C. \& Attwood, E. C. (1974) Clin. Chim. Acta 53, 101-108.

4. Pinnell, A. E. \& Northam, B. E. (1978) Clin. Chem. 24, $80-86$, and references cited therein.

5. Ingwersen, S. \& Raabo, E. (1978) Clin. Chim. Acta 88, $545 \div 550$.
In the Dutch quality control program our deviations from the means of albumin values can for the greater part be explained by the use of a nonhuman control serum. Some commercially available non-human control sera were estimated, and showed the same tendency.

If the bromocresol purple method is used, it should be emphasized that very misleading results could be given to the clinic, if the origin of the standard serum is not checked. With the bromocresol purple method a human calibration serum is necessary.

Despite some disadvantages of the bromocresol green method, we believe that for emergency determinations of albumin the bromocresol green method is still preferable to the bromocresol purple method. In other cases the more specific immuno chemical methods are to be preferred.

Very recently Ingwersen \& Raabo (5) described a modified method of Doumas et al (1) for the determination of serum albumin with bromocresol green. We carried out some experiments with their bromocresol green method (5), "our" bromocresol green method (2), and a combination of total protein and protein scan. With Ingwersen's bromocresol green method we obtained lower values than were obtained with "our" bromocresol green method. Comparable values of their bromocresol green method and the total protein/protein scan method were found. Despite some misleading misprints in Ingwersen \& Raabo's paper their modification seems to be useful because of better circumstances for the determination of serum albumin with bromocresol green.

In quality control programs using non-human control sera, large deviations from the true albumin value can be obtained when using different dying techniques.

Results can only be compared when the methods are specified.

\section{Acknowledgement}

The authors thank Miss W. E. Weide for carrying out the Mpartigen immunodiffusion experiments.
6. Gustafsson, J. E. C. (1978) Clin. Chem. 24, 369-373.

7. Cederblad, G., Hickey, B. E., Hollander, A. \& Akerland, G. (1978) Clin. Chem. 24, 1191-1193.

8. Carter, P. (1970) Microchem. J. 15, 531-539.

9. Louderback, A., Mealey, E. H. \& Taylor, N. A. (1968) Clin. Chem. 14, 793-794.

10. Haythorn, P. \& Sheehan, M. (1979) Clin. Chem. 25, 194.

11. Peters, T. (1970 Adv. Clin. Chem. 13, 37-111.
Drs. G. T. Berends

Clinical Chemical Laboratory

St. Elisabeth's Hospital

Boerhaavelaan 22

NL-2035 RC Haarlem.

The Netherlands. 


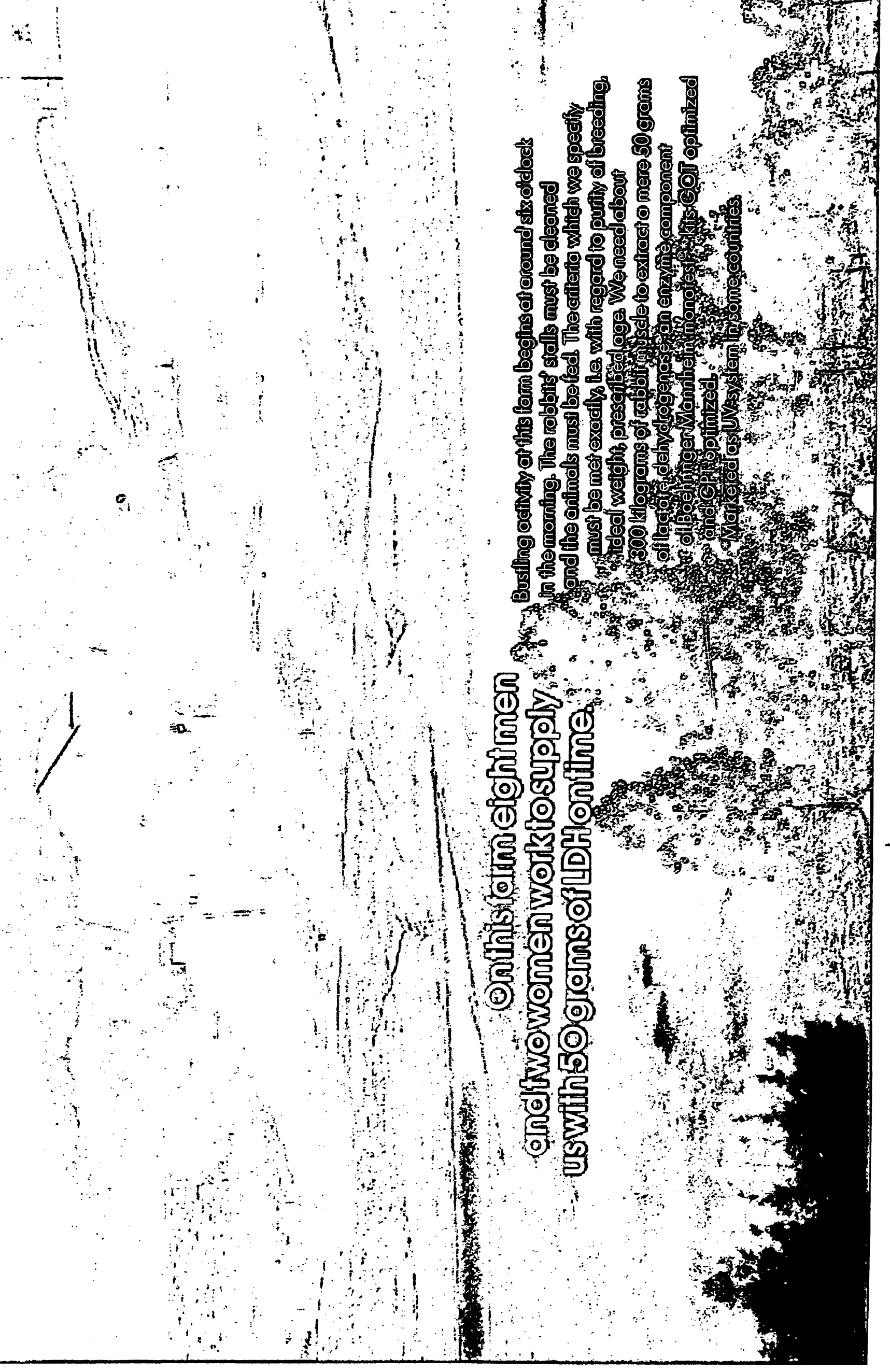




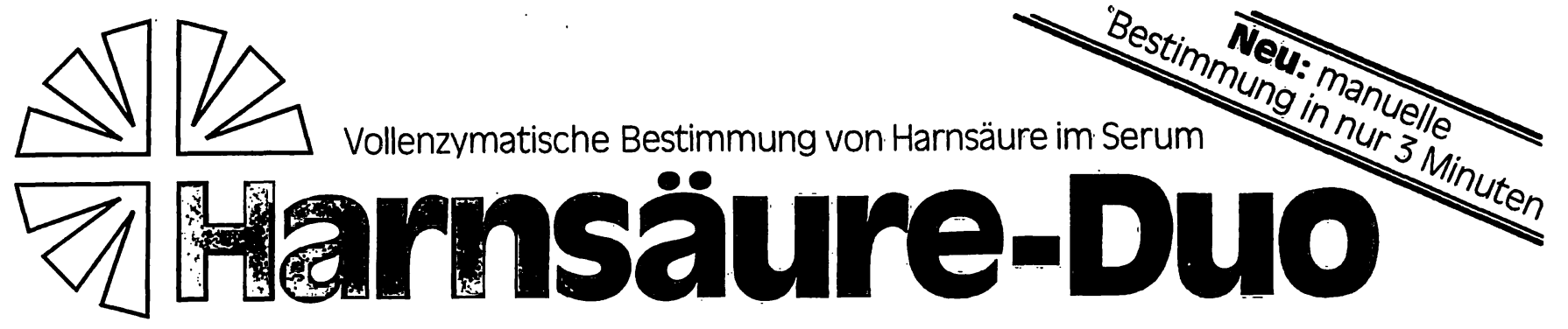

\section{Die schnelle Bestimmung bei Raumtemperaturp}

Vorteile der Methode:

* schnell - da Reaktionszeit nur 15 Minuten

* einfach - da nur ein Pipettierschritt

- da Probenleerwert usw. entfällt

- da arbeiten bei Raumtemperatur

* spezifisch - da vollenzymatische Bestimmung * automatisierbar als Kinetik- und Endpunkt-

Bestimmung

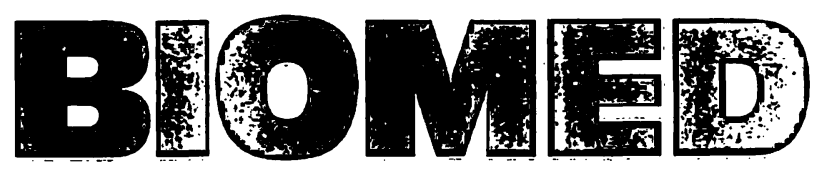

Labordiagnostik $\mathrm{CmbH}$

Grashofstraße $73 \cdot 8000$ München 50

Telefon (089) $3145100 \cdot$ Telex 5216278

\section{RÖMPPS CHEMIE LEXIKON}

\section{DAS STANDARDWERK DER CHEMIE}

8. Auflage von Dr. O.-A. Neumüller in 6 Bänden

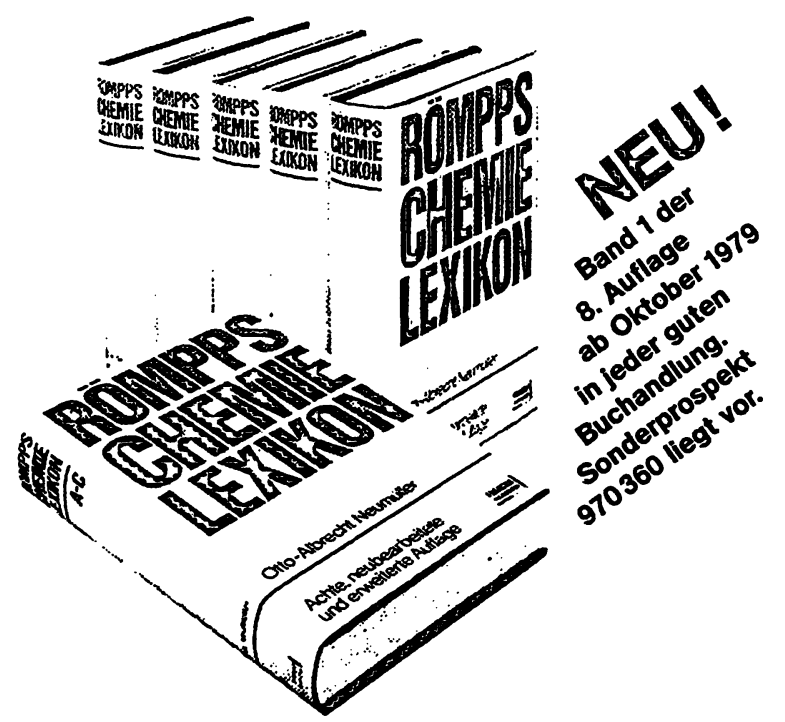

Band I (A-C), ca. 800 Seiten mit ca. 250 SchwarzweiBzeichnungen im Text, gebunden. DM 165,- Subskriptionspreis bis zum Erscheinen des 2. Bandes.

Späterer Ladenpreis DM 195,- (Preisänderungen während des Erscheinens des Werkes vorbehalten). Von den Bänden II-VI erscheint mindestens 1 Band jährlich. Die Abnahme des 1 . Bandes verpflichtet zur Abnahme des Gesamtwerkes. Einzelbände sind nicht erhältlich. Bestell-Nr. ISBN 3-440-04510-2.

Franckh'sche Verlagshandlung · Stuttgart

\begin{tabular}{ll}
\hline $\begin{array}{l}\text { W } \\
\text { of }\end{array}$ & Walter de Gruyter \\
Berlin. New York
\end{tabular}

\section{Vitamin $\mathbf{B}_{\mathbf{1 2}}$}

\section{Proceedings of the Third European Symposium on Vitamin $\mathbf{B}_{\mathbf{1 2}}$}

Editors

B. Zagalak, W. Friedrich

$1979.17 \mathrm{~cm} \times 24 \mathrm{~cm}$.

Approx. 1100 pages. Hardcover.

Approx. DM 190,-; \$112.00

ISBN 3110076683

Price is subject to change 